E-ISSN. 2685-7650

Vol 3 No 1 (2021) pp 44-55

Artikel Disubmit 28 April $2021 \bullet$ Revisi 28 Mei $\bullet$ Revisi Diterima 14 Juni

\title{
Kesetaraan Gender dalam Konstruksi Media Sosial
}

\author{
Wicha Rizky Sakti Mashito Widodo ${ }^{1}$, Nurudin ${ }^{2}$, Widiya Yutanti ${ }^{3}$ \\ ${ }^{1,2,3}$ Program Studi Ilmu Komunikasi, Universitas Muhammadiyah Malang \\ Email: e.wicharizky.207@gmail.com
}

\begin{abstract}
Patriarchy results in gender inequality in the social environment. This makes women and men have roles, status and even emotional levels that tend to discriminate. So that researchers are interested in analyzing and criticizing gender inequality in Indonesia through campaigns carried out by the @lawanpatriarki and @lakilakibaru Instagram accounts, where the two accounts have different backgrounds but have one goal. This research uses a qualitative approach with a critical paradigm and an interpretive type. As for the data collection methods used are screenshots of posts on gender equality content and captions on Instagram accounts @lawanpatriarki and @lakilakibaru, notes, journals, books, and articles on the website or the internet. This data collection is used to obtain information regarding the messages that the two accounts convey in the 'Free from Sexual Violence' campaign posts. Then, the data is processed using a discourse analysis text study of Sara Mills. From The research conducted shows that the differences in the background of two accounts have the same goal, namely to voice gender equality which applies to all parties, both men, women and others. Everyone has the right to feel free from sexual violence, especially from the shackles of a patriarchy culture. This is because the patriarchy culture is not only detrimental to women but also men.
\end{abstract}

Keywords: social media construction; gender equality; instagram; rape

\begin{abstract}
Abstrak: Budaya patriarki di Indonesia masih melekat erat, di mana belum adanya kesetaraan gender secara nyata dalam kehidupan sehari-hari. Banyak anggapan bahwa perempuan dan laki-laki memiliki peran, status bahkan sampai tingkat emosional yang cenderung mendeskriminasi Oleh sebab itu, peneliti tertarik untuk menganalisa dan mengkritisi ketidaksetaraan gender di Indonesia melalui kampanye yang dilakukan akun Instagram @lawanpatriarki dan @lakilakibaru, di mana kedua akun tersebut memiliki background yang berbeda namun satu tujuan. Penelitian menggunakan pendekatan kualitatif dengan paradigma kritis dan tipe interpretatif. Sedangkan untuk metode pengumpulan data yang digunakan adalah tangkapan layar postingan konten-konten kesetaraan gender dan caption di akun instagram @lawanpatriarki dan @lakilakibaru, catatan, jurnal, buku-buku, dan artikel yang ada dalam website atau internet. Pengumpulan data ini digunakan untuk mendapatkan informasi menganai pesan-pesan yang disampaikan kedua akun tersebut pada postingan kampanye 'Bebas dari Kekerasan Seksual'. Kemudian, data tersebut diolah menggunakan kajian teks analasis wacana Sara Mills. Dari penelitian yang dilakukan menunjukkan bahwa dengan perbedaan background kedua akun tersebut memiliki tujuan yang sama, yaitu menyuarakan kesetaraan gender berlaku untuk semua pihak, baik laki-laki, perempuan dan lainnya. Semua orang berhak merasakan kebebesan dari kekerasan seksual, terlebih dari belenggu budaya patriarki. Sebab, budaya patriarki tersebut tidak hanya merugikan perempuan tapi juga laki-laki.
\end{abstract}

Kata Kunci: konstruksi media social; kesetaraan gender; instagram; pemerkosaan

\section{Pendahuluan}

Budaya patriarki di Indonesia masih melekat erat dengan mindset masyarakatnya, di mana belum adanya kesetaraan gender secara nyata dalam kehidupan sehari-hari. Misalnya saja, perempuan dianggap "bukan perempuan baik" apabila ada gambar tattoo dalam tubuhnya, merokok, pulang malam, rambut diwarna selain hitam dan masih banyak hal lainnya yang 
dianggap biasa apabila laki-laki yang melakukannya. Contoh nyata dalam kehidupan sosial lakilaki akan dianggap aneh dan feminim apabila menyukai warna cerah, seperti pink. Laki-laki juga tidak diperkenankan melakukan perawatan diri, mulai dari skincare sampai bodycare. Bahkan laki-laki di budaya patriarki yang memiliki image kuat dilarang menangis. Perempuan terdoktrin menjadi dua spesifikasi, yaitu "perempuan baik-baik" dan "bukan perempuan baik-baik". Seperti yang dipaparkan Santi, dalam Susilo dan Haezer yang mengungkapkan adanya "perempuan baik-baik" dan "bukan perempuan baik-baik" menjadi pelabelan dari media untuk perempuan (D. \& E. H. Susilo, 2017). Penggambaran oleh media pada perempuan tentu mempengaruhi opini publik sebagaimana fungsi dari media massa dalam kehidupan bermasyarakat. Kasus Agni, mahasiswi UGM yang dilecehkan teman KKN-nya bukanlah kasus pertama mengenai pemerkosaan yang ditindaklanjuti dengan tidak adil di Indonesia. Agni pun sempat disudutkan dengan cibiran "Salah sendiri kok mau, nggak malah ngelawan?"dan cemooh sejenis lainnya. Selain itu, kasus besar yang menjadikan laki-laki sebagai korban kekerasan seksual juga minim perhatian publik dibanding jika perempuan korbannya seperti yang terjadi pada kasus kekerasan seksual "Gilang Bungkus".

Selain memiliki peranan menggiring opini publik, media juga berperan sebagai hakim paling benar dan sah-sah saja untuk mengeskploitasi perempuan demi kepuasan pembaca lakilaki seperti yang diungkapkan Ahmad Junaidi, Redaktur "The Jakarta Post" (D. Susilo, 2014). Media massa memiliki peran penting yang mana digunakan dalam penyampain informasi secara luas. Sebab, media massa bisa menjangkau publik dalam lingkup yang lebih besar (Tamburaka, 2012). Apalagi, di era digital yang segalanya serba canggih dan cepat dengan bantuan internet memudahkan media massa untuk menyampaikan informasi kepada khalayak. Sangat disayangkan jika media belum bisa menerapkan jurnalistik gender dalam penyajian beritanya. Hal-hal yang berkaitan dengan perempuan seolah menjadi bahan komersil bagi media tersebut. Susilo juga memaparkan bahwa media daring memberikan kepuasan fantasi dan imaji bagi pembaca laki-laki dengan hasrat seksualitas dalam berita (D. Susilo, 2014).

Peran gender dalam dunia jurnalistik memang sedikit rancu bagi banyak orang. Pada dasarnya perbedaan antara laki-laki dan perempuan dapat diwakili oleh dua konsep, yaitu jenis kelamin (sex) dan gender (Tamburaka, 2012). Perbedaan jenis kelamin lebih mengacu pada perbedaan fisik antara laki-laki dan perempuan, terutama pada perbedaan fungsi reproduksi. Sedangkan untuk gender adalah konstruksi sosio-kultural yang tidak harus berdasarkan dari jenis kelamin. Gender membagi atribut dan pekerjaan menjadi dua, yaitu "maskulin" dan "feminim". Namun kesalahpahaman ini masih melekat pada masyarakat sekitar. Banyak orang awam yang belum memahaminya. Tidak hanya dari framing media pada perempuan dan laki-laki yang berbeda serta bisa menggiring opini publik, tapi juga bagaimana masyarakat itu sendiri memberi label pada perempuan di kehidupan sehari-hari. Budaya patriarki ini tentu saja berdampak besar pada kehidupan bersosial yang mana lebih besar merugikan pihak perempuan. Patriarki menimbulkan masalah sosial yang membelenggu kebebesan dan hak perempuan (Sakina, 2017). Sehingga perempuan hanya diberikan wilayah sebatas pekerjaan domestik atau rumah tangga. Sementara itu, laki-laki identik dengan pekerjaan di ranah publik, mulai dari menjadi kepala keluarga dan juga pemimpin dalam keluarga (Omara, 2014).

Seperti yang diutarakan Kepala Adat Kamama di Maluku yang merupakan subsukubangsa bermukim di Pulau Seram, Provinsi Maluku bahwa perempuan itu punya kedudukan yang lebih rendah dari laki-laki karena perempuan itu sewaktu-waktu mengalami menstruasi 
yang dianggap mendapat kotor (Nina, 2012). Budaya patriarki tidak tumbuh mentah-mentah dari media massa yang bisa dibilang baru dalam kehidupan manusia. Namun, masyarakat itu sendiri yang membentuk stigma budaya patriarki dari kepala suku atau kepala adat dengan otomatis diikuti oleh masyarakatnya. Patriarki adalah sebuah sistem sosial yang menempatkan laki-laki sebagai pemegang kekuasaan tertinggi dan mendominasi peran kepemimpinan politik, otoritas, moral, hak sosial dan penguasaan properti. Keberadaan paham patriarki ini tidak lepas dari sejarah peradaban manusia.

Media sosial yang merupakan bagian dari media massa memiliki peranan dalam membentuk dan menggiring opini publik, apalagi media sosial kini jauh lebih digemari masyarakat daripada kanal berita. Dengan adanya gadget yang seolah tidak pernah lepas dari tangan kita membuat dunia terasa seperti dalam genggaman. Banyak aplikasi di media sosial yang ditawarkan dengan ciri khas masing-masing dengan fungsi untuk memudahkan penggunanya berhubungan. Dengan ini, perbedaan jarak dan waktu pun tidak terasa karena kita tetap bisa berkomunikasi dengan orang-orang di beda daerah bahkan negara. Sebab, media sosial adalah unit yang ada pada media online, yaitu media online atau media daring yang dimanfaatkan sebagai sarana berhubungan atau lebih tepatnya pergaulan secara online di jaringan internet (Maxmanroe, 2018). Belum lagi, penggunaan media sosial yang menyediakan fitur chat seperti Facebook, Twitter hingga Instagram.

Asal mula kata Instagram menurut Putri dalam Ghoni berasal dari kata "insta" atau "instan", maksudnya instagram bisa mempublikasikan gambar secara instan. Kemudian, kata "gram" merujuk dari kata telegram yang fungsinya untuk mengirimkan informasi secara cepat (Ghoni, 2018). Kertamukti juga membagikan pendapatnya bahwa Instagram merupakan aplikasi untuk saling berbagi foto yang mana pengikut dari pengunggahnya dapat melihatnya serta saling berinteraksi dalam memberikan komentar (Kertamukti, 2015). Tidak heran hal ini membuat Instagram menjadi media sosial yang digemari oleh masyarakat, khususnya di Indonesia. Pada Januari di tahun 2018 lalu, pengguna instagram di dunia mencapai 800 juta orang (Data, 2018). Hal ini disebabkan oleh pemanfaatan Instagram yang menguntungkan selain sebagai wadah berbagi foto dan video, juga bisa menjadi ladang bisnis. Indonesia sendiri menempati posisi ketiga sebagai pengguna Instagram terbanyak di dunia setelah Amerika Serikat dan Brazil, dengan mencapai angka 53 juta.

Menurut Siti Muslichatul Mahmudah dan Muthia Rahayu dalam Jurnal Komunikasi Nusantara, Instagram bisa digunakan dalam perangkat mobile yang bisa dibawa ke manapun, seperti smartphone, tablet hingga laptop. Hal ini membuat masyarakat mudah mengakses Instagram di manapun dan kapanpun. Selain itu, Instagram juga bisa menyambungkan akun penggunanya dengan platform media sosial lainnya. Sehingga memudahkan untuk sekali mengunggah konten di Instagram bisa langsung disebarkan ke platform lainnya, seperti WhatsApp, Twitter hingga Facebook. Apalagi Instagram menghadirkan fitur hashtag yang membuat penggunanya bisa langsung menuju topik yang dihendaki saja (Mahmudah, 2020).

Akun Instagram @lawapatriarki dan @lakilakibaru cukup menarik untuk diteliti karena mengedukasi masyarakat agar kesetaraan gender benar-benar dirasakan di semua pihak baik dari sudut pandang perempuan maupun laki-laki. Peneliti meneliti salah satu akun opini publik di Instagram @lawanpatriarki. Akun ini mengunggah berbagai opini dari banyak influencer, edukasi serta informasi pentingnya diberlakukan kesetaraan gender. Akun @lawanpatriarki memiliki jumlah followers sekitar 107 ribu hingga 5 November 2019 dengan jumlah postingan 
mencapai hingga 1.781. Akun ini mulai berdiri pada tahun 2018, tepatnya postingan pertama yang diupload pada 30 September 2018. Konten yang diunggah berisi opini-opini yang melawan patriarki di Indonesia. Akun @lawanpatriarki mengedukasi dan bertukar pendapat dengan banyak orang, khususnya pengikutnya agar kesetaraan gender benar-benar bisa dirasakan oleh semua pihak. Akun ini juga mengajak kita agar bisa bijak dalam bersikap dan saling menghargai, khususnya sesama perempuan. Beberapa influencer Instagram seperti Gitasav, Rachel Venya dan masih banyak lagi yang mendukung kesetaraan gender juga turut mengedukasi di akun ini.

Akun@lakilakibaru merupakan gerakan laki-laki untuk kesetaraan gender. Berbeda dengan @lawanpatrarki yang dikelola perempuan, sesuai namanya akun ini dikelola oleh lakilaki. Akun ini memang belum seramai @lawanpatriarki meskipun berdiri lebih dulu yaitu 30 Maret 2015. Terlihat dari jumlah pengikutnya yang masih di angka 6.885 dengan postingan 374 sampai April 2021. Namun, gerakan yang dikampanyekan di akun ini tentu berbeda dan bisa dianggap baru seperti namanya yang mendukung kesetaraan gender dan melawan budaya patriarki oleh kaum laki-laki. Maka dari itu, peneliti tertarik untuk membandingkan konten kesetaraan gender yang berfokus pada isu pemerkosaan dari sudut pandang akun @lawanpatriarki dan @lakilakibaru. Apalagi kasus pelecehan seksual di Indonesia sendiri hukumnya belum jelas dan tegas. Terkait \#SahkanRUUPKS saja dari tahun 2017 hingga penelitian ini dilakukan, yaitu di tahun 2019 belum mendapatkan kejelasan dari pemerintah. Inilah yang menjadi topik utama dalam akun Instagram @lawanpatriarki dan@lakilakibaru. Berdasarkan fenomena yang sudah dijabarkan, penelitian ini dilakukan dengan tujuan untuk mengkritisi bentuk konstruksi isu kesetaraan gender pada akun Instagram @lawanpatriarki dan @lakilakibaru.

\section{Metode Penelitian}

Penelitian ini memanfaatkan metode penelitian kualitatif dan paradigma kritis. Tujuannya untuk mendapatkan informasi secara detail dan mendalam terkait fenomena sosial sebagai suatu proses secara kritis yang berusaha mengungkapkan struktur yang sebenarnya di balik ilusi. Selain itu juga untuk meningkatkan kesadaran sosial agar mampu memperbaiki dan merubah kondisi kehidupan manusia. Sedangkan penggunaan paradigma kritis bertujuan untuk mengkritik sosial, transformasi, emansipasi dan pemberdayaan sosial. Sifat dari paradigma kritis berupa selalu menaruh rasa curiga serta mempertanyakan situasi masyarakat sosial (Prestita Ishaya, 2016). Peneliti menggunakan paradigma kritis sebab dianggap bahwa konten di akun @lawanpatriarki dan @lakilakibaru mendukung kesetaraan gender dari pihak perempuan dan laki-laki. Peneliti berusaha mengungkap bagaimana tujuan dari admin-admin akun tersebut untuk mendukung kesetaraan gender melalui ide, gambar, poster yang ada di postingan Instagram-nya. Sedangkan pendekatan yang digunakan adalah kualitatif di mana memiliki kelebihan kesederhanaan dan bisa dianalisis secara langsung dikarenakan memiliki bentuk skala atau nilai yang bisa diartikan (Machmud, 2018). Tujuannya adalah mendapatkan makna, pengertian atau ideologi, konsep dan juga pengembangan teori baru.

Dasar penelitian yang digunakan adalah kajian teks analisis wacana kritis, yaitu mengartikan wacana tidak hanya sebagai studi kebahasaan tapi juga menghubungkan konteks, yang mana maksudnya adalah praktik kekuasaan dengan tujuan untuk membedakan individu atau kelompok tertentu. Sehingga, konteks sosial bisa dipengaruhi oleh wacana itu sendiri. Fairclough dalam Machmud menyatakan bahwa wacana berbentuk "praktik sosial" yang 
berhubungan dengan adanya dialektika dalam sebuah bahasa dan kondisi sosial (Machmud, 2018). Analisis wacana dimanfaatkan untuk menemukan timpanganya kekuasaan di tengah masyarakat, sekaligus menaruh curiga dan meyelidiki aspek kebahasaan oleh kelompok sosial yang saling bertentangan untuk membenarkan ideologi yang diusung masing-masing.

Penelitian ini menitikberatkan terhadap konten tentang kekerasan seksual di akun @lawanpatriarki dan@lakilakibaru. Konten yang sama namun dengan caption yang berbeda. Peneliti ingin menganalisa bagaimana kesetaraan gender pada isu pemerkosaan dari kedua akun tersebut dengan cara membandingkan dari sudut pandang yang berbeda, yaitu akun yang dikelola perempuan dan laki-laki. Peneliti akan menganalisa kontennya yang meliputi gambar dan tulisan beserta umpan balik audiens berupa fitur likes. Sedangkan untuk batas waktu analisa sesuai dengan waktu diunggahnya konten tersebut. Konten isu pemerkosaan yang diunggah akun Instagram @lawanpatriarki dan @lakilakibaru bertepatan saat ramainya isu RUU PKS di Indonesia dan juga momen Hari Kemerdekaan, tepatnya pada bulan Agustus 2019. Akun Instagram @lawanpatriarki mengunggah pada tanggal 17 Agustus sedangkan @lakilakibaru sehari setelahnya, yaitu 18 Agustus 2019. Peneliti memilih momentum Agustus 2019 karena saat itulah pertama kali publik gencar mengkampanyekan \#SahkanRUUPKS. Sementara itu, untuk instrument penelitian yang dipergunakan adalah peneliti sendiri karena terlibat langsung dalam menganalisa topik yang sudah ditentukan.

Kemudian, metode pengumpulan data akan dijadikan informasi oleh peneliti. Beberapa data yang digunakan berupa tangkapan layar postingan konten-konten kesetaraan gender beserta caption di akun Instagram @lawanpatriarki dan @lakilakibaru, catatan, jurnal, buku-buku, juga artikel yang ada dalam website atau internet dan wawancara dengan Hudaniah, S. Psi., M.Si., Kepala Bimbingan Konseling Universitas Muhammadiyah Malang. Tujuan dari pengumpulan data tersebut guna memperoleh informasi yang bisa memperkuat analisis peneliti dan bisa menginterpretasi data. Sedangkan untuk tekniknya menggunakan analisis wacana kritis milik Sara Mills karena berpandangan bahwa teks adalah hasil dari negoisasi pembaca dan penulis (Badara, 2012). Analisis wacana ini menitikberatkan tentang perempuan selama ini disajikan dalam teks. Menurut Mills dalam Machmud, perempuan selalu dipinggirkan dalam teks dan berada diposisikan secara tidak tepat bahkan tanpa diberikan kesempatan membela diri terlebih dulu (Machmud, 2018). Tujuannya adalah membangun asumsi dalam gaya konvesional menjadi lebih jelas, dengan tidak sekedar menambahkan topik gender ke dalam daftar objek yang dianalisa tapi juga menggunakan stilistika sebagai tahapan baru dalam analisis wacana. Mills juga membantah pandangan banyak ahli yang hanya mempelajari dan menempatkan konteks pada penulis. Menurutnya ada kelebihan jika melihat pembaca juga yaitu lebih komprehensif melihat teks bukan hanya dari faktor produksi tapi juga resepsi. Mills membagi tiga level untuk melakukan analisis wacana, yaitu a) Analisis pada level kata, b) Analisis pada level frasa/kalimat, dan c) Analis pada level wacana, karakter atau peran (Machmud, 2018).

\section{Hasil dan Pembahasan}

Hasil penelitian diperoleh berdasarkan analisa peneliti terhadap konten mengenai isu pemerkosaan di akun Instagram @lawanpatriarki dan @lakilakibaru. Dua akun ini mengkampanyekan konten yang sama namun memiliki caption dan waktu pengunggahan yang berbeda. Jika dilihat dari jumlah likes, akun @lawanpatriarki memiliki reaksi yang lebih besar dibanding @lakilakibaru. Sesuai dengan analisis wacana Sara Mills, konten terkait kampanye isu 
pemerkosaan (kekerasan seksual) pada akun @lawanpatriarki dan @lakilakibaru dilakukan dengan menganalisa pada tahapan level kata, kemudian dilanjutkan pada level kalimat, lalu level wacana.

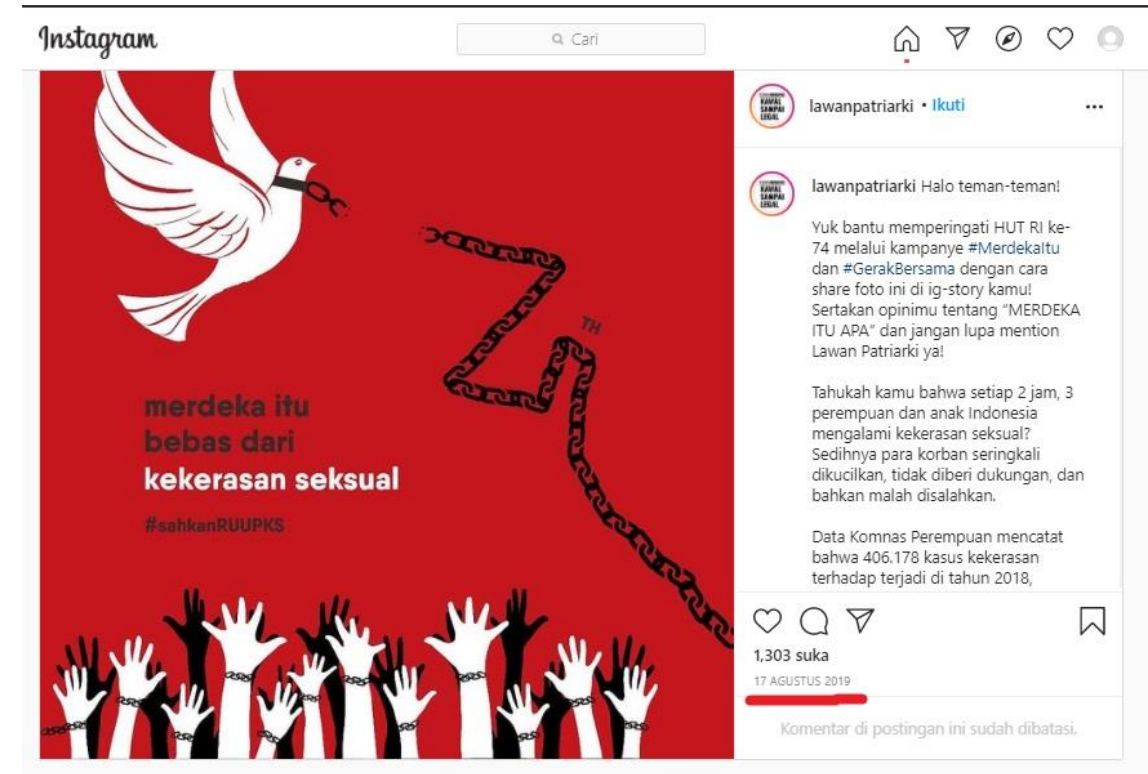

Gambar 1.1 Konten Akun Instagram @lawanpatriarki yang dianalisa yaitu kampanye kekerasan seksual termasuk pemerkosaan.

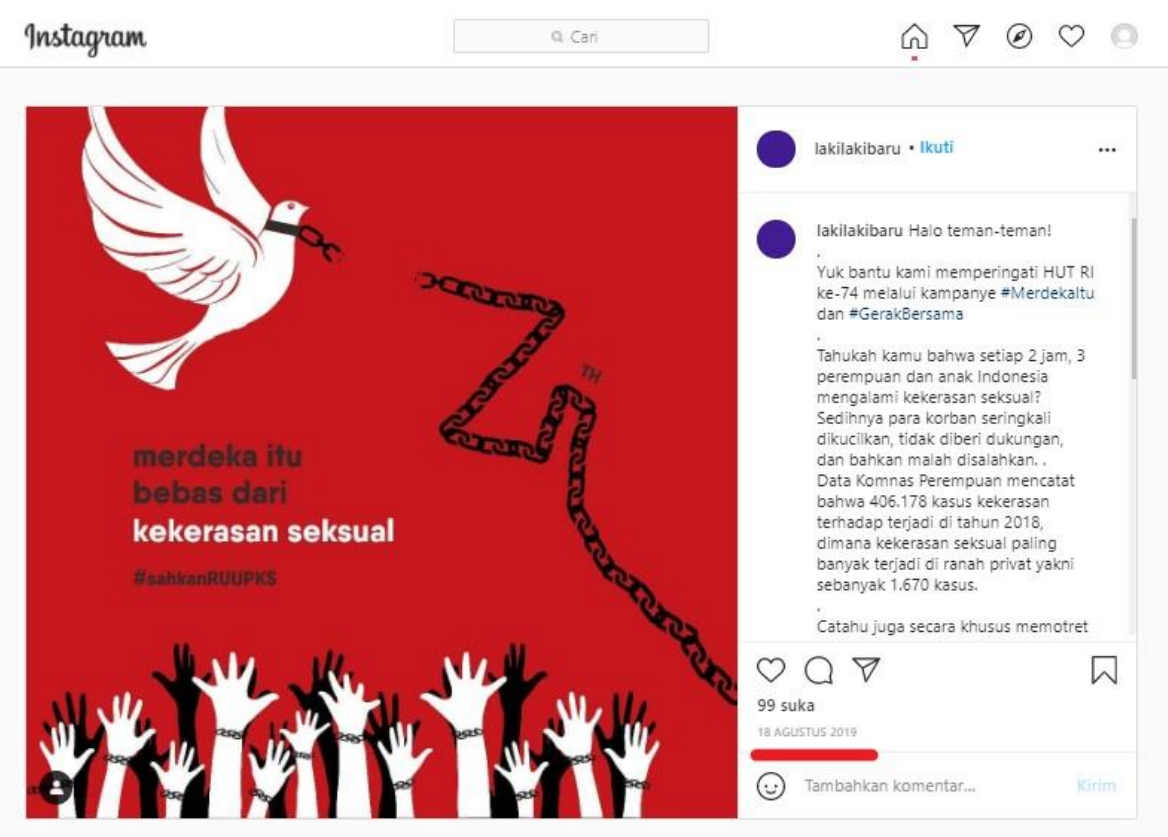

Gambar 1.2 Konten Akun Instagram @lakilakibaru yang dianalisa yaitu kampanye kekerasan seksual termasuk pemerkosaan.

Pada unggahan akun Instagram @lawanpatriarki yang dirilis pada 17 Agustus 2019 terdapat poster dengan background merah yang mengkampanyekan gerakan anti kekerasan seksual. Sedangkan akun @lakilakibaru mengunggah poster tersebut sehari setelahnya, yaitu pada tanggal 18 Agustus 2019. Poster ini bermaksud untuk menyuarakan gerakan kepada pemerintah agar mengesahkan RUU PKS. Selain itu kampanye tentang isu pemorkosaan ini juga 
tercantum pada caption dari unggahan tersebut. Lewat poster yang diunggah akun Instagram @lawanpatriarki dan @lakilakibaru terdapat kata "kekerasan seksual" dan juga tagar \#sahkanruupks. Kata-kata inilah yang mendapat sorotan karena akun @lawanpatriarki dan @lakilakibaru mengkampanyekan kemerdekaan seseorang itu bebas dari adanya kekerasan seksual berdasarkan tatanan hukum yang jadi patokan dan pedoman. Pemilihan waktu mengunggahnya pun bertepatan dengan perayaan Hari Kemerdekaan bangsa Indonesia yaitu 17 Agustus. Saat itulah Indonesia memerdekakan diri sebagai suatu bangsa dan bebas dari penjajahan negara asing. Itu kenapa poster ini memilih menggunakan kata 'kebebasan' untuk hal seksual bagi semua rakyat Indonesia dengan disahkannya RUU PKS.

Poster ini sangat menggambarkan bagaimana protes kepada pemerintah untuk segera mengesahkan RUU PKS agar terbebas dan merdeka dari belenggu kekerasa seksual yang hukumnya tidak jelas akibat budaya patriarki yang masih ada. Apalagi kasus pemerkosaan di Indonesia yang kian hari bertambah namun jeratan hukum bagi pelakunya belum bisa memerdekakan korban.Isu pemerkosaan di Indonesia pun menjadi topik panas yang dibicarakan, ditambah banyaknya korban yang justru disalahkan atau mendapat perlakuan tidak menyenangkan akibat pengaruh budaya patriarki yang masih kental, sesuai yang disampaikan oleh kedua akun Instagram, @lawanpatriarki dan @lakilakibaru. Padahal, seperti yang dijelaskan Joseph dan Savitri segala tindakan yang dilakukan dengan paksaan sekalipun tanpa adanya penetrasi termasuk dalam pemerkosaan (Joseph, 2019). Hal ini juga disebabkan dari niat pelaku melakukan tindakan tersebut, bukan karena penampilan korban pemerkosaan.

Patriarki di Indonesia sendiri sudah melekat sejak lama, bahkan dari budaya dan adat istiadat terdahulu. Di Maluku misalnya, dipercaya bahwa perempuan memiliki kedudukan yang lebih rendah dari laki-laki. Kepala Adat Kamana di Maluku yang bermukim di Pulau Seram menyatakan karena perempuan mengalami menstruasi dianggap kotor dan hal ini sudah ada dari dulu kala yang berlangsung secara turun-temurun meskipun mereka sendiri tidak tahu asal muasalnya dari mana (Nina, 2012). Budaya patriarki ini berperan besar terhadap kedudukan lakilaki dan perempuan. Mulai dari peran sosial, pendidikan, pekerjaan sampai hak-hak hidup lainnya. Menurut Ratnawati, adanya diskriminasi pendidikan antara laki-laki dan perempuan disebabkan adanya patriarki yang mendominasi (Sulistyorini, 2019). Itu kenapa tagar \#Sahkanruupks juga dicantumkan dalam poster yang diunggah @lawanpatriarki dan @lakilakibaru sebagai kampanye agar pemerintah segera mengesahkan RUU PKS sebab penting adanya sebagai landasan hukum kasus kekerasan seksual di Indonesia.

Dalam caption yang digunakan akun Instagram @lawanpatriarki maupun @lakilakibaru dalam unggahan kebebasan dari kekerasan seksual tersebut menggunakan kata-kata korban, dikucilkan, disalahkan, kekerasan seksual, dunia maya, revenge porn, malicious distributions, cyber harassment, impersonation, cyber stalking dan sexting. Hal ini menunjukkan bahwa banyaknya bentuk kekerasan seksual yang terjadi di dunia maya. Ditambah para korban selama ini justru lebih disalahkan daripada mendapat dukungan untuk memperoleh keadilan dari kekerasan seksual yang dialaminya. Mulai dari pakaiannya hingga sikap korban. "Pasti bajunya menggoda" "Makanya jaga penampilan" "Kucing dikasih ikan asin yang terbuka ya nggak nolak" dan ungkapan-ungkapan lainnya. Padahal, di sini korban kekerasan seksual adalah pihak yang dirugikan baik secara fisik maupun mentalnya. Itu kenapa tidak sedikit juga para korban justru memilih bungkam dan menyembunyikan fakta bahwa ia menjadi korban. Menutupinya karena takut dicela, disalahkan dan malu. Timbul trauma dan kesehatan psikis korban yang 
terganggu. Ada beberapa dampak yang bisa ditimbulkan dari adanya kekerasan seksual seperti yang diutarakan Kustanty, yaitu dampak fisik, dampak psikis, dampak seksual dan dampak ekonomis (Kustanty, 2018). Hal ini juga sesuai dengan apa yang diungkapkan Joseph, selain bentuk luka fisik yang bisa terjadi pada korban, juga kemungkinan besar mengalami sindrom trauma perkosaan atau biasa disebut Rape Trauma Syndroms (RTS).

Hampir sama dengan pendapat Joseph, menurut Faturochman dampak yang ditimbulkan dari tindakan perkosaan pada fisik korban bisa berupa kerusakan organ tubuh seperti robeknya selaput dara, pingsan bahkan meninggal. Korban juga bisa terkena Penyakit Menular Seksual (PMS) dan kehamilan yang tidak dikehendaki. Selain itu juga bisa menimbulkan syok dan trauma jangka pendek maupun panjang. Apalagi, di masyarakat Indonesia ada stigma yang dibentuk kalau perempuan korban pemerkosaan adalah perempuan yang hina. Menurut Taslim (1995) dalam Faturochman juga mengatakan bahwa adanya pandangan yang seringkali menyalahkan perempuan korban pemerkosaan. Taslim juga menambahkan bahwa masyarakat melabeli perempuan korban pemerkosaan sebagai "penggoda" atau "menantang" laki-laki dengan memakai pakaian ketat, rok mini, seksi yang sengaja mengundang nafsu birahi laki-laki pemerkosa (Sulistyaningsih Faturochman, 2002).

Selain kemungkinan-kemungkinan yang disebutkan oleh Joseph, korban pemerkosaan juga bisa mencurigai orang lain dalam waktu yang lama. Dampak psikologis yang ditimbulkan juga bisa membuat korban terdorong melakukan bunuh diri akibat trauma yang hebat. Penelitian dari majalah MS Magazine mengatakan bahwa 30\% perempuan korban pemerkosaan mengalami bunuh diri, $31 \%$ mencari psikoterapi, $22 \%$ mengambil kursus bela diri dan $82 \%$ mengatakan bahwa pengalaman tersebut telah mengubah mereka secara permanen yang artinya tidak bisa dilupakan (Sulistyaningsih Faturochman, 2002). Kekerasan seksual juga tidak hanya terjadi di lingkungan sekitar secara langsung. Tapi juga banyak yang terjadi di dunia maya. Mulai dari komentar-komentar yang dituliskan, mengirim teks, foto atau video tidak senonoh melalui Direct Message (DM) Instagram, Twitter dan sebagainya. Hal ini berarti bahwa kampanye yang dilakukan@lawanpatriarki @lakilakibaru di sini sesuai dengan apa yang selama ini terjadi, bahwa, korban kekerasan seksual belum merasakan kebebasannya akibat belenggu budaya patriarki. Ditambah tidak adanya kejelasan hukum di Indonesia selama bertahun-tahun lamanya karena pemerintah belum juga mengesahkan RUU PKS. Kampanye ini juga disampaikan melalui media sosial sebab seperti yang kita tahu, media sosial menjadi sarana yang tepat untuk menyampaikan informasi secara meluas. Apalagi, para oknum juga bisa melakukan kekerasan seksual lewat dunia maya. Itu kenapa hashtag \#SahkanRUUPKS juga jadi sorotan pada kampanye yang dilakukan akun Instagram @lawanpatriaki dan@lakilakibaru yang mana pada Undang-Undang tersebut kasus kekerasan seksual di Indonesia bisa diadili.

Aspek lain yang telah disoroti adalah penggunaan tagar pada caption konten yang diunggah akun@lawanpatriarki dan @lakilakibaru. Terdapat tagar \#hijrah di akhir caption selain tagar \#sahkanRUUPKS. Tagar tersebut menjadi sorotan karena di Indonesia budaya patriarki cenderung dekat dengan suatu kaum agama di Indonesia yang mana menyebutkan bahwa laki-laki sebagai penguasa nomor satu. Sedangkan perempuan disebutkan memiliki kodrat tertentu seperti harus di rumah, harus lemah lembut, tidak boleh pakai baju terbuka, tidak boleh merokok bahkan tidak boleh menjadi pemimpi dan lain sebagainya sedangkan laki-laki diperbolehkan. Sebagian orang-orang yang mengaku hijrah atau melakukan perubahan lebih baik ini juga merasa dirinya paling benar dan tidak sensitif gender. Justru mereka cenderung 
menerapkan budaya patriarki. Bahkan ada suatu kasus suami memperkosa istri namun beberapa kaum yang mengaku berhijrah menentang hal itu dan sudah seharusnya seorang istri melayani suami apapun kondisinya.

Dalam sebuah artikel yang diterbitkan tirto.id dengan judul "Perkosaan dalam Perkawinan Itu Nyata dan Bisa Membunuhmu" menjelaskan bagaimana fenomena perkosaan dalam rumah tangga yang dilakukan suami atau istri dianggap tabu (Putri, 2019). Justru sudah seharusnya pasangan suami istri berhubungan badan meskipun dalam paksaan. Seolah perempuan mau tidak mau harus melayani suaminya dan pernikahan sebatas hubungan badan saja. Padahal, seperti yang disampaikan Joseph Nina bahwa pemerkosaan sebagai perbuatan pemaksaan kehendak seseorang terhadap orang lain yang dalam hal ini bentuknya berupa melakukan perbuatan seksual. Siapapun itu yang memaksa bahkan suami/istri sekalipun jika mengajak berhubungan badan dengan paksaan termasuk tindakan perkosaan (Nina, 2012)

Setelah menganalisa pada level kata, selanjutnya adalah kalimat yang tercantum pada unggahan akun Instagram @lawanpatriarki dan @lakilakibaru terkait isu kekerasan seksual. Kalimat yang terdapat pada poster dengan background merah, yaitu 'Merdeka itu bebas dari kekerasan seksual \#sahkanRUUPKS' menjadi kampanye kedua akun Instagram tersebut. Kedua akun Instagram tersebut mengkampanyekan keadaan di Indonesia sebagaimana harusnya bebas termasuk para korban kekerasan seksual. Selain itu, penggunaan kalimat pada poster sangat menarik, singkat, padat dan jelas, 'Merdeka itu bebas dari kekerasan seksual, sahkan RUU PKS' yang bermaksud kebebasan itu harus dirasakan semua rakyat Indonesia termasuk bebas dari kekerasan seksual. Maka dari itu, pemerintah seharunya mengesahkan RUU PKS sebagai landasan hukum yang jelas terkait kekerasan seksual dalam bentuk apapun dan keadilan untuk para korban. Selanjutnya pada caption yang diunggah akun@lawanpatriarki dan @lakilakibaru hampir sama. Hanya saja terdapat sedikit perbedaan di mana akun @lawanpatriarki membuat kalimat ajakan kepada pengikutnya atau pengguna Instagram lainnya untuk ikut meramaikan kampanye ini agar RUU PKS segera disahkan.

Selain itu juga caption poster tersebut menandakan bahwa kampanye ini berangkat dari data yang jelas dan sesuai fakta yang terjadi di lapangan. Selain itu, bentuk kekerasan seksual juga kian marak terjadi bahkan hingga di dunia maya. Itu berarti kekerasan seksual tidak hanya perlu diwaspadai saat di dunia nyata saja namun juga di dunia maya. Terdapat pula kalimat 'Ayo bantu hapuskan kekerasan seksual dengan mem-post foto di atas beserta tagar \#MerdekaItu dan \#GerakBersama di tanggal 17-19 Agustus ya!' di akun Instagram @1akilakibaru yang diawali dengan kata 'Ayo' untuk menyerukan ajakan meramaikan kampanye tersebut dengan menyertakan foto dan tagar \#MerdekaItu dan \#GerakBersama. Kalimat inilah yang ditambahkan akun @lakilakibaru untuk mengajak para pengguna Instagram khususnya pengikut akun tersebut. Sehingga gerakan lewat poster tersebut dilakukan secara bersama-sama untuk memerangi kekerasan seksual.

Setelah diteliti dengan dua tahapan, yaitu pada level kata dan level kalimat, analisis dilanjutkan pada level wacana, karakter atau peran. Dimulai dari unsur warna yang digunakan untuk poster kampanye di akun Instragam @lawanpatriarki dan @lakilakibaru. Bertepatan dengan momentum Hari Kemerdekaan Indonesia, kedua akun Instagram tersebut menggunakan kata-kata bernuansa kebebasan dan warna merah untuk background poster dan putih untuk tulisan serta gambar burung yang identik dengan Bendera Merah Putih. Seperti yang kita tahu merah dan putih merupakan identitas dari warna bendera Merah Putih Indonesia. Merah juga 
melambangkan arti keberanian sedangkan putih kesucian. Itu berarti akun @lawanpatriarki dan @lakilakibaru berani dalam mengkampanyekan kebebesan kekerasan seksual untuk seluruh rakyat Indonesia. Warna putih digunakan pada tulisan 'Kekerasan Seksual' yang mana menjadi sorotan dan poin utama dari poster tersebut. Hal ini juga menggambarkan sarkasme yang mana putih identik dengan lambing kesucian, kebersihan, kepolosan sedangkan kekerasan seksual adalah sebaliknya.

Namun maksud penggunaan warna putih pada kata tersebut adalah agar fenomena ini bisa teratasi dengan baik sesuai hukum yang setimpal. Selain itu juga menjadi harapan ke depannya dengan ada kampanye untuk pemerintah segera mengesahkan RUU PKS ini kekerasan seksual di Indonesia bisa tertasai. Warna putih juga terdapat pada gambar burung yang bisa terbang bebas karena berhasil lepas dari jeratan rantai berwarna hitam. Gambar burung ini merepresentasikan bagaimana bebas dari belenggu kekerasan seksual. Selain warna merah dan putih yang kental akan suasana Hari Kemerdekaan Indonesia, terdapat juga warna hitam yang digunakan untuk beberapa kata dan gambar rantai. Pada tulisan 'Merdeka itu bebas dari' dan '\#sahkanRUUPKS' menggunakan warna hitam dan ukurannya lebih kecil dibanding kata 'Kekerasan Seksual'. Kalimat merdeka itu bebas' dari berwarna hitam karena menunjukkan sarkasme di mana rakyat Indonesia belum sepenuhnya bebas dari kekerasan seksual apapun itu bentuknya. Terbukti dari bagaimana fenomena kekerasan seksual di Indonesia yang belum bisa diatasi dengan baik dan hukumnya belum jelas untuk para pelakunya. Hal itu menjadi alasan kalimat pada poster dibumbui dengan '\#sahkanRUUPKS' yang dikampanyekan akun Instagram @lawanpatriarki dan @lakilakibaru agar pemerintah segera melakukan pengesahan RUU PKS. Jika tidak maka rakyat Indonesia belum bisa sepenuhnya merasakan kebebesan sesungguhnya karena masih terbelenggu 'Kekerasan Seksual' dan budaya patriarki yang sibuk menyalahkan korban daripada menghukum para pelakunya.

Selain itu, terbelenggunya dengan kekerasan seksual ini digambarkan dengan rantai berwarna hitam yang tadinya menjerat burung dara. Poster ini memiliki arti sarkasme di mana 'Kekerasan Seksual' harusnya bisa diatasi sehingga bisa terbebas dari belenggu rantai yang diartikan sebagai budaya patriarki di Indonesia. Itu kenapa warna hitam dipilih untuk gambar rantainya. Warna hitam juga di sana yang mana identik dengan tegas, kelam dan gelap. Budaya patriarki yang masih kental digambarkan dengan warna hitam yang mana arti sebenarnya Indonesia belum benar-benar bebas dan merdeka karena terikat budaya patriarki dan kekerasan seksual yang marak di mana-mana. Itu kenapa penting adanya penerapan kesetaraan gender. Adanya kesetaraan gender, pembedaan peran, perilaku, karakteristik, mentalitas sampai emosional laki-laki dan perempuan akan dianggap sama. Selain itu, juga keduanya bisa samasama berkembang tanpa adanya suatu diskriminasi pada salah satu pihak (Mestiani, 2015). Hal lain yang juga dianalisa dalam studi ini adalah kenapa Instagram yang dipilih sebagai platform penyebaran kampanye ini. Sebab, seperti data yang didapatkan peneliti bahwa Instagram adalah akun media sosial yang digemari oleh masyarakat, khususnya di Indonesia. Menurut data yang disampaikan oleh hasil survei WeAreSocial.net dan HootSuite, Instagram adalah akun yang memiliki pengguna paling banyak ketujuh di dunia. Pada Januari di tahun 2018 lalu, pengguna instagram di dunia mencapai 800 juta orang (Data, 2018). Indonesia sendiri menempati posisi ketiga sebagai negara dengan pengguna Instagram terbanyak di dunia setelah Amerika Serikat dan Brazil, dengan mencapai angka 53 juta. Maka dari itu kampanye yang dilakukan melalui 
Instagram bisa sesuai sasaran yang dituju sekaligus meningkatkan rasa waspada masyarakat Indonesia.

\section{Kesimpulan}

Dari hasil penelitian mengenai bagaimana konstruksi isu kesetaraan gender pada akun Instagram@lawanpatriarki dan@lakilakibaru, dapat disimpulkan bahwa budaya patriarki di Indonesia masih melekat erat sehingga menimbulkan adanya ketidaksetaraan gender. Ditambah, hal ini juga merambah ke media sosial yang mengakibatkan banyaknya bentuk kekerasan seksual terjadi. Bahkan, kekerasan seksual tidak hanya dialami perempuan sebagai korban, tapi juga bisa terjadi pada laki-laki. Oleh sebab itu, peneliti menganalisa fenomena ini yang dikampanyekan oleh dua akun dengan sudut pandang berbeda, yaitu dari pihak perempuan maupun laki-laki yang sama-sama bertujuan menyuarakan kesetaraan gender. Apalagi kasus kekerasan seksual di Indonesia juga tidak memiliki landasan hukum yang mana sampai sekarang pemerintah belum mengesahkan RUU PKS. Itu sebabnya, kedua akun Instagram tersebut mengkampanyekan gagasan kesetaraan gender melalui poster mengenai merdeka itu bebas dari kekerasan seksual dengan adanya pengesahan RUU PKS. Kedua akun tersebut juga memilih momentum pada bulan Agustus 2019 untuk kampanye yang sesuai dengan Hari Kemerdekaan Indonesia. Itulah mengapa pemilihan kata-kata, gambar serta warna pada poster juga sesuai dengan nuansa Hari Kemerdekaan Indonesia.

Akun Instagram @lawanpatriarki dan @lakilakibaru tidak hanya mengkampanyekan dan mengajak pengikutnya untuk meramaikan tagar \#sahkanRUUPKS, tapi juga memberikan informasi dengan data akurat dari Komnas HAM dan CATAHU Komnas Perempuan tahun 2019 tentang bagaimana kekerasan seksual di Indonesia. Dari data tersebut, audiens menjadi tahu bentuk-bentuk kejahatan seksual, apalagi yang marak terjadi di dunia maya serta pentingnya RUU PKS untuk segera ditindaklanjuti oleh pemerintah Indonesia. Mereka juga memberikan edukasi terkait kekerasan seksual di Indonesia harus seperti apa ditindak dan memberikan keadilan kepada korbannya. Sehingga kesetaraan gender bisa dirasakan oleh semua pihak untuk meminimalisir budaya patriarki yang sudah lama tertanam di rakyat Indonesia.

Kedua akun tersebut juga memanfaatkan platform Instagram yang mana memang menjadi kegemaran rakyat Indonesia dengan jumlah pengguna terbanyak ketiga di dunia tahun 2019. Sehingga, sasaran audiens-nya jadi lebih banyak terjangkau jika kampanye dilakukan melalui Instagram. Kemudian, juga dapat disimpulkan bahwa teori analisis wacana yang dikemukakan Sara Mills sesuai dengan objek penelitian di lapangan. Analisis wacana tidak hanya memperhatikan kebahasaan dalam teks tapi juga konteks yang meliputi banyak hal seperti gambar, audio, simbol-simbol, musik dan lain sebagainya.

\section{Daftar Pustaka}

Badara, A. (2012). Analisis Wacana: Teori, Metode, dan Penerapannya pada Wacana Media. Kencana.

Data, K. (2018). Berapa Pengguna Instagram dari Indonesia. Kata Data. https://databoks.katadata.co.id/datapublish/2018/02/09/berapa-pengguna-instagram-dariindonesia

Ghoni, M. F. A. (2018). Penggunaan Instagram Sebagai Media Dakwah. Universitas Islam Negeri Walisongo. 
Joseph, N. (2019). Mengulik Beragam Jenis Perkosaan dan Dampaknya Bagi Korban, Secara Fisik dan Mental. Hello Sehat. https://hellosehat.com/hidup\%0Asehat/psikologi/jenis-dandampak-pemerkosaan/\%0A

Kertamukti, R. (2015). Instagram dan Pembentukan Citra. 8, No.1, 65.

Kustanty, U. F. (2018). Pencegahan, Perlindungan dan Penanganan Kekerasan terhadap Anak dan Remaja. Jurnal Harkat Media Komunikasi Gender, 145. http://journal.uinjkt.ac.id/index.php/psga/article/view/12817/pdf

Machmud, M. (2018). Tuntunan Penulisan Tugas Akhir Berdasarkan Prinsip Dasar Penelitian Ilmiah. Selaras.

Mahmudah, S. M. \& M. R. (2020). Pengelolaan Konten Media Sosial Korporat Pada Instagram Sebuah Pusat Perbelanjaan. Jurnal Komunikasi Nusantara, $2,3$.

Maxmanroe. (2018). Pengertian Media Sosial Secara Umum, Fungsi, Tujuan, Jenis Sosmed. Maxmanroe. https://www.maxmanroe.com/vid/teknologi/internet/pengertian-mediasosial.html

Mestiani, W. (2015). Keadilan Gender Dalam Penilaian Hasil Belajar. 7, No.2, 302.

Nina, J. (2012). Perempuan Nuaulu Tradisionalisme Dan Kultur Patriarki. Yayasan Pustaka Obor Indonesia.

Omara, A. (2014). Perempuan, Budaya Patriarki dan Representasi. Mimbar Hukum, 148. http://ilib.ugm.ac.id/jurnal/detail.php?dataId=2625

Prestita Ishaya, C. (2016). Analisis Wacana Sara Mills Dalam Film Dokumenter Battle for Sevastopol [Universitas Islam Negeri Syarif Hidayatullah]. http://repository.uinjkt.ac.id/dspace/bitstream/123456789/35168/1/CORRY PRESTITA ISHAYA-FDK.pdf

Putri, A. W. (2019). Perkosaan dalam Pernikahan Itu Nyata dan Bisa Membunuhmu. Tirto.Id. https://tirto.id/perkosaan-dalam-perkawinan-itu-nyata-dan-bisa-membunuhmu-ejBL

Sakina, A. I. \& D. H. S. A. (2017). Menyoroti Budaya Patriarki di Indonesia. 7, No.1, 129.

Sulistyaningsih Faturochman, E. (2002). Dampak Sosial Psikologis Perkosaan. 10, No.1, 23. https://jurnal.ugm.ac.id/buletinpsikologi/article/view/7448/5789

Sulistyorini, D. R. \& A. Z. A. (2019). Kesetaraan Gender Tentang Pendidikan Laki-laki dan Perempuan. Jurnal Harkat Media Komunikasi Gender, $1,4$. http://journal.uinjkt.ac.id/index.php/psga/article/view/13436/pdf

Susilo, D. (2014). Jurnalisme Tidak Peka Gender. 12. https://www.researchgate.net/publication/302955581_JURNALISME_TIDAK_PEKA_GE NDER_Studi_Analisis_Wacana_Pemberitaan_Perempuan_Oleh_Media_Online_Tribunnew scom

Susilo, D. \& E. H. (2017). Konstruksi Seksualitas Perempuan Dalam Berita Pemerkosaan Di Teks Media Daring. 1, 2. https://jurnal.ugm.ac.id/kawistara/article/view/15636/17326

Tamburaka, A. (2012). Agenda Setting Media Massa. PT RajaGrafindo Persada. 